\title{
Pengaruh Lumpur Sawit Terhadap Daya Simpan dan Palatabilitas Pakan Pellet Kelinci
}

\author{
The Effect Of Solid Decanter On Storability And Palatabilty Of Rabbit Pellet Feed
}

\author{
Amir Husaini Karim Amrullah ${ }^{1}$, Fregi Fehriansah ${ }^{1}$, dan Irma Badarina ${ }^{1}$ \\ ${ }^{1}$ Jurusan Peternakan, Fakultas Pertanian, Universitas Bengkulu \\ Jalan Raya W. R. Supratman, Kandang Limun, Kota Bengkulu, 38371 \\ Corresponding e-mail: amir.hk.amrullah@ unib.ac.id 082177314824
}

\begin{abstract}
The study aims to evaluate the use of palm decanter on storability and palatability of pellet rabbit feed. There were four treatments, $\mathrm{P} 0$ : rabbit pellets $0 \%$ palm decanter, $\mathrm{P} 1$ : rabbit pellets $5 \%$ palm decanter, $\mathrm{P} 2$ : rabbit pellets $10 \%$ palm decanter, P3: rabbit pellets $15 \%$ palm decanter. Pellets are prepared based on the standard nutritional needs of rabbits. Pellets were stored in $0.5 \mathrm{~kg}$ plastic bags for $0,7,14$, and 21 days. Moisture, crude fat, and organoleptic content were carried out on pellet with storage times $0,7,14$, and 21 days. Organoleptic was carried out by 20 panelists. Palatability was carried out for a pellet with seven days of storage and given to 5 rabbits. The moisture and crude fat content of pellet in all treatments ranged from 8.63-10.17\%. The higher the palm decanter content, the pellet color tends to be black with a value of 2.64.3. The use of $15 \%$ palm decanter can cause pellets to have a slightly rancid aroma and a characteristic solid odor. The use of $15 \%$ palm decanter did not have a significant effect on rabbit feed consumption with the consumption range 74.93-145.73 g. The study concluded that rabbit pellets containing up to $15 \%$ palm mud with a storage time of 21 days did not reduce storability. Pellets containing up to $15 \%$ palm mud with a storage time of 7 days did not reduce palatability in rabbits.
\end{abstract}

Key Words: Palm decanter, pellet, rancidity, feed, palatability

\begin{abstract}
ABSTRAK
Penelitian bertujuan mengevaluasi penggunaan lumpur sawit terhadap daya simpan dan palatabilitas pakan kelinci berbentuk pellet. Terdapat 4 perlakuan, P0: pellet kelinci 0\% lumpur sawit, P1: pellet kelinci 5\% lumpur sawit, P2: pellet kelinci 10\% lumpur sawit, P3: pellet kelinci d 15\% lumpur sawit. Pellet disusun berdasarkan standar kebutuhan nutrisi kelinci. Pellet disimpan dalam kantong plastik berukuran $0,5 \mathrm{~kg}$ selama 0, 7, 14 dan 21 hari. Kadar air, lemak kasar dan organoleptik dilakukan pada pellet dengan lama penyimpanan $0,7,14$, dan 21 hari. Organoleptik dilakukan oleh 20 orang panelis. Palatabilitas dilakukan untuk pellet dengan lama penyimpanan 7 hari dan diberikan pada 5 ekor kelinci. Kadar air dan lemak kasar pellet seluruh perlakuan berkisar antara 8,63-10,17\%. Semakin tinggi kandungan lumpur sawit maka warna pellet cenderung berwarna hitam dengan nilai 2,6-4,3. Penggunaan 15\% (P3) lumpur sawit dapat menyebabkan pellet beraroma agak tengik dan berbau khas solid. Penggunaan 15\% (P3) lumpur sawit tidak memberikan pengaruh yang nyata pada konsumsi pakan kelinci dengan kisaran konsumsi 74,93-145,73 g. Kesimpulan penelitian bahwa pellet kelinci yang mengandung lumpur sawit sampai 15\% dengan lama simpan 21 hari tidak menurunkan daya simpan. Pellet yang mengandung lumpur sawit sampai dengan $15 \%$ dengan lama simpan 7 hari tidak menurunkan palatabilitas pada kelinci.
\end{abstract}

Kata Kunci: Lumpur sawit, pellet, ketengikan, pakan, palatabilitas

\section{PENDAHULUAN}

Keberhasilan usaha ternak dipengaruhi terutama oleh pakan. Sebanyak $70 \%$ biaya produksi ternak digunakan untuk pakan. Pemahaman terhadap manajemen pakan menjadi sangat penting. Salah satu upaya dengan pemanfaatan limbah pertanian yang dijadikan sebagai pakan alternatif ternak dan dapat membantu untuk meminimalisir biaya pakan. Limbah pertanian dapat digunakan sebagai bahan pakan pengganti, yaitu dengan mengganti bahan pakan yang memiliki harga yang 
tinggi dengan bahan yang lebih murah tanpa mengurangi kandungan gizi dan ketersediaan bahan pengganti.

Memanfaatkan limbah pertanian dan perkebunan dapat menjadi salah satu alternatif dalam mengatasi permasalahan ketersedian dan biaya pakan. limbah yang saat ini cukup potensial sebagai pakan ternak karena jumlah, kualitas dan harganya adalah limbah sawit. Limbah dari industri pemrosesan buah kelapa sawit yang dapat dimanfaatkan sebagai pakan diantaranya lumpur sawit atau solid dan bungkil inti sawit. Keunggulan dalam penggunaan limbah perkebunan sebagai sumber bahan pakan adalah dikarenakan produksi melimpah, murah dan mudah didapat. Limbah perkebunan biasanya akan terkonsentrasi pada wilayah industri perkebunan tertentu, dimana pemanfaatannya secara ekonomi dapat berkontribusi pada pendapatan perusahaan dan membantu kegiatan pengawasan lingkungan yang dapat mengurangi pencemaran dari limbah industri perkebunan (Said, 1996).

Setiap $1000 \mathrm{~kg}$ produksi minyak sawit akan dihasilkan sekitar dua sampai tiga ton lumpur sawit (Direktorat Jenderal Perkebunan, 2012). Lumpur sawit memiliki kandungan zat gizi berupa serat kasar 21,15 \%, protein kasar $12,17 \%$, selulosa $11,42 \%$, lemak 19,96 \%, lignin 36,40 \% dan hemiselulosa 18,77 \% (Lekito, 2002). Lumpur sawit mempunyai kelemahan daya simpan tidak lama. Hal ini disebabkan pada lumpur sawit mengandung 1,50\% CPO yang akan menyebabkan berbau tengik jika disimpan pada tempat terbuka serta akan ditumbuhi jamur atau kapang yang berwarna putih. Salah satu teknologi pengolahan bahan pakan yaitu dengan menjadikan campuran bahan pakan menjadi pellet.

Pellet merupakan campuran bahan pakan yang telah melalui proses pemadatan dan pencetakan dengan mengeluarkannya dari sebuah die melalui proses mekanik (Nilasari, 2012). Pellet merupakan suatu bentuk pakan buatan yang dibuat dari berbagai macam bahan pakan yang diramu dan dijadikan adonan, kemudian dicetak sehingga membentuk batangan atau bulatan kecilkecil. Ukuran pellet bervariasi berkisar antara satu sampai dua $\mathrm{cm}$. Sehingga bentuk pellet tidak berupa tepung, butiran, dan tidak berupa larutan (Zang et al., 2009). Dengan teknologi pembuatan pellet. lumpur sawit selain dapat tahan lama, juga dapat menjadikan kandungan nutrisinya lebih lengkap dengan adanya bahan pakan lain yang ditambahkan seperti garam mineral sehingga dapat meningkatkan palatabilitas ternak.

Lumpur sawit memiliki aroma yang khas, hal ini dapat mempengaruhi aroma pakan. Jumlah lumpur sawit dalam pakan akan mempengaruhi aroma pakan yang akan berdampak pada palatabilitas pakan. Palatabilitas merupakan tingkat kesukaan yang ditunjukkan ternak dalam mengkonsumsi suatu bahan pakan yang diberikan pada periode tertentu. Rasa, Tekstur, aroma dan warna, yang disukai ternak dapat menunjukkan bahwa kualitas pakan sangat baik yang dapat 
berpengaruh terhadap palatabilitas. Kualitas pakan juga dipengaruhi oleh lama penyimpanan, dimana pakan yang disimpan melebihi batas waktu tertentu akan turun kualitasnya. Sehingga pemanfaatan lumpur sawit sebagai bahan baku pembuatan pellet pakan ternak perlu dievaluasi baik dari segi jumlah maupun kualitas pelletnya.

\section{MATERI DAN METODE}

\section{Pembuatan Pakan}

Lumpur sawit yang digunakan terlebih dahulu dijemur sampai kering matahari dan digiling sampai halus. Pembuatan pakan dilakukan dengan cara mencampur seluruh bahan sesuai dengan proporsi masing-masing perlakuan (Tabel 1). Penyusunan pakan sesuai dengan kebutuhan nutrisi kelinci (Blas dan Wiseman, 2010). Pencampuran pakan dilakukan dengan cara mencampur bahanbahan pakan yang memiliki partikel yang halus selanjutnya baru-bahan pakan dengan partikel yang lebih kasar. Setelah bahan tercampur selanjutnya bahan diberi air 2 gelas ukuran $200 \mathrm{ml}$ yang sudah dipanaskan untuk $2 \mathrm{~kg}$ ransum dan aduk sampai merata. Kemudian bahan pakan dicetak berbentuk pellet. Selanjutnya pakan dijemur sampai kering. Pellet yang sudah kering kemudian dimasukkan dalam kantong plastik ukuran 0,5 kg sebanyak $200 \mathrm{~g}$ dan ditempatkan dalam suhu ruang.

Tabel 1. Komposisi bahan pakan pembuatan pellet yang digunakan dalam penelitian

\begin{tabular}{|c|c|c|c|c|}
\hline Bahan Pakan & $\mathrm{P} 0(\%)$ & $\mathrm{P} 1(\%)$ & $\mathrm{P} 2(\%)$ & $\mathrm{P} 3(\%)$ \\
\hline Lumpur sawit & 0 & 5 & 10 & 15 \\
\hline Konsentrat & 15,00 & 15,00 & 14,50 & 14,00 \\
\hline Jagung giling & 31,50 & 29,50 & 30,00 & 29,50 \\
\hline Dedak padi & 32,00 & 30,00 & 25,00 & 21,00 \\
\hline Premix & 0,50 & 0,50 & 0,50 & 0,50 \\
\hline Bungkil sawit & 6,00 & 6,00 & 6,00 & 6,00 \\
\hline Bungkil kedelai & 15,00 & 14,00 & 14,00 & 14,00 \\
\hline Bahan kering $^{*}$ & 88,20 & 88,35 & 88,55 & 88,74 \\
\hline Protein kasar & 16,78 & 16,69 & 16,73 & 16,77 \\
\hline Serat kasar ${ }^{*}$ & 10,33 & 11,33 & 11,94 & 12,69 \\
\hline Lemak kasar ${ }^{*}$ & 4,73 & 5,00 & 5,32 & 5,64 \\
\hline
\end{tabular}

Sumber : Nilai gizi diperoleh dari hasil perhitungan

\section{Persiapan Kandang}

Pemeliharaan kelinci menggunakan kandang individu yang ditempatkan pada Commercial Zone and Animal Laboratory (CZAL) Jurusan Peternakan, Fakultas Pertanian, Universitas 
Bengkulu. Kandang tersebut berukuran $50 \mathrm{~cm}$ x $40 \mathrm{~cm}$ x $30 \mathrm{~cm}$. Kandang terbuat dari bahan besi baik lantai dan dinding kandangnya dan juga dilengkapi dengan tempat pakan dan minum kelinci.

\section{Rancangan Penelitian}

Penelitian menggunakan Rancangan Acak Lengkap (RAL) yang terdiri dari 4 perlakuan dan 5 ulangan: $\mathrm{P} 0=$ pellet dengan $0 \%$ lumpur sawit $\mathrm{P} 1=$ pellet dengan $5 \%$ lumpur sawit $\mathrm{P} 2=$ pellet dengan 10\% lumpur sawit P3 = pellet dengan $15 \%$ lumpur sawit.

\section{Daya simpan.}

Daya simpan dilakukan dengan mengukur kadar air, kadar lemak kasar, warna, bau dengan lama penyimpanan $0,7,14$, dan 21 hari. Parameter warna dan bau menggunakan 10 orang panelis.

Tabel 2. Skala Pengujian Organoleptik

\begin{tabular}{clll}
\hline \multirow{2}{*}{ Skala } & \multicolumn{2}{c}{ Kriteria } \\
\cline { 2 - 4 } & Warna Pellet & Bau Pellet & Bau Solid \\
\hline 1 & Sangat Coklat & Sangat tengik & sangat berbau solid \\
2 & Coklat & Tengik & Berbau solid \\
3 & Agak coklat & Agak tengik & Agak berbau solid \\
4 & Coklat kehitaman & Tidak tengik & Tidak berbau solid \\
5 & Hitam & Tidak tengik sekali & sangat tidak berbau solid \\
\hline
\end{tabular}

\section{Palatabilitas}

Palatabilitas diujikan menggunakan 5 ekor kelinci dengan berat yang sama dan dibagi secara acak. Untuk masing-masing perlakuan pengujian dibagi menjadi 2 tahap yaitu tahap I pengujian palatabilitas P1 \& P3 dan tahap II pengujian palatabilitas P0 \& P2. Pellet yang diujikan adalah pellet yang telah disimpan 7 hari. Palatabilitas dilihat dengan memberikan pellet pada kelinci selama 3 hari dengan diberikan dua kali sehari yaitu pada pagi dan sore hari. Konsumsi pellet kelinci dicatat setiap hari. Pemberian pakan perlakuan sebanyak $6 \%$ dari bobot badan.

\section{Analisis data}

Data kadar lemak kasar dan kadar air dianalisis secara deskriptif. Data palatabilitas dianalisis menggunakan ANOVA dengan kepercayaan 95\%, dan dilanjutkan dengan uji Duncan's Multiple Range Test (DMRT). Data warna dan bau dianalisis secara deskriptif menggunakan skala likert.

\section{HASIL DAN PEMBAHASAN}

\section{Kadar air dan lemak kasar}

Kandungan kadar air dan lemak kasar pada pellet kelinci yang mengandung lumpur sawit dengan berbagai konsentrasi disajikan pada Tabel 3. 
Tabel 3. Kandungan air dan lemak kasar dalam pelllet pada penyimpanan 0-21 hari

\begin{tabular}{llcccc}
\hline Parameter & Pengamatan & \multicolumn{4}{c}{ Perlakuan } \\
\cline { 3 - 6 } & & P0 & P1 & P2 & P3 \\
\hline Kadar air (\%) & Hari ke 0 & 8,63 & 9,04 & 9,10 & 9,63 \\
& Hari ke 7 & 10,17 & 10,42 & 9,04 & 9,67 \\
& Hari ke 14 & 9,96 & 10,25 & 9,91 & 11,80 \\
& Hari ke 21 & 9,95 & 9,68 & 9,88 & 10,79 \\
\hline Lemak kasar (\%) & Hari ke 0 & 3,18 & 3,41 & 3,89 & 4,18 \\
& Hari ke 7 & 4,10 & 3,77 & 3,93 & 3,73 \\
& Hari ke 14 & 2,80 & 2,73 & 2,31 & 2,11 \\
& Hari ke 21 & 2,53 & 4,62 & 4,00 & 4,62 \\
\hline
\end{tabular}

Keterangan : P0 : Tanpa mengandung lumpur sawit. P1 : 5\% Penggunaan lumpur sawit. P2 : 10\% Penggunaan lumpur sawit. P3 : 15\% Penggunaan lumpur sawit.

Berdasarkan hasil penelitian kadar air pellet kelinci dengan penyimpanan hari ke 0 sampai hari ke 21 dengan level lumpur sawit $0 \%$ sampai 15\% berkisar antara 8,63\% sampai 11,80\%. Penyimpanan pellet akan meningkatkan kandungan kadar air akibat adanya pengaruh dari kelembaban udara dan suhu lingkungan lokasi penyimpanan. Amiroh (2008) mengungkapkan apabila kadar air bahan rendah sedangkan kelembaban udara sekitarnya tinggi, hal ini akan menyebabkan terjadinya penyerapan uap air dari udara yang dapat menyebabkan pakan menjadi lembab sehingga kandungan kadar airnya menjadi lebih tinggi.Tingginya kandungan kadar air dalam suatu bahan pakan akan membuat penyimpanan tidak lama. Menurut Trisyulianti et al. (2003), kandungan kadar air yang berkisar antara 12\%-14\% dapat menekan aktivitas mikroorganisme, yang akan menjadikan bahan pakan tidak mudah berjamur dan membusuk.

Hasil yang diperoleh pada uji kadar lemak kasar yaitu semakin tinggi persentase lumpur sawit pada pakan akan meningkatkan kandungan kadar lemak kasar. Kadar lemak kasar yang didapat pada penelitian ini kisaran 2,11\%-4,62\% sesuai dengan kadar lemak kasar yang dibutuhkan oleh kelinci, karena kebutuhan kadar lemak kasar kelinci 2-5\%. Menurut Junaida (2013) menyatakan bahwa kadar lemak kasar yang dibutuhkan kelinci berkisar antara 2 - 6\%. Petterson (1989) menyatakan faktor-faktor yang dapat berperan dalam mempercepat proses kerusakan lemak yaitu kandungan minyak pada pakan ataupun kontak langsung dengan udara, temperatur ruangan, cahaya, kadar air bahan dan adanya katalis. Rusaknya lemak dalam pakan saat penyimpanan ditandai dengan adanya ketengikan serta meningkatnya serangan jasad renik yang diakibatkan adanya keterkaitan antara tekanan uap, kadar air, dan kelembaban. Kadar air, suhu dan kelembaban adalah faktor penentu terjadinya kerusakan lemak kasar yang diakibatkan oleh 
mikroorganisme. Pengemasan dan penyimpan yang sesuai akan mengurangi adanya resiko pertumbuhan mikroorganisme, sehingga perubahan kadar lemak kasar dapat diminimalisir.

Kandungan kadar lemak kasar yang tinggi akan berpengaruh pada penyimpan, semakin tinggi kadar lemak kasar maka penyimpanan tidak tahan lama. Menurut Haryanto (2012), pada ternak ruminansia kandungan lemak kasar dalam pakan disarankan tidak melebihi 5\%. Hal ini dikarenakan kandungan lemak yang tinggi akan mempengaruhi aktivitas mikroba rumen, yang dapat menurunkan populasi mikroba pencerna serat. Kandungan Lemak yang tinggi pada pakan akan mengakibatkan ketengikan sehingga dapat memperpendek daya simpan pakan tersebut (Kompiang et al.,1997).

\section{Warna dan Aroma}

Rataan uji warna bau pellet dan bau solid pada pellet kelinci yang mengandung lumpur sawit disajikan pada Tabel 4.

Tabel 4. Rataan uji warna, bau pellet, dan bau lumpur sawit pada pellet dengan lama penyimpanan 0-21 hari

\begin{tabular}{llllll}
\hline \multirow{2}{*}{ Parameter } & Pengamatan & \multicolumn{3}{c}{ Perlakuan } \\
\cline { 2 - 5 } & Hari ke 0 & 2,6 & 3,0 & 3,7 & P0 \\
\hline Warna & Hari ke 7 & 2,5 & 2,7 & 3,1 & 3,3 \\
& Hari ke 14 & 2,6 & 2,7 & 3,0 & 3,2 \\
& Hari ke 21 & 2,1 & 2,5 & 2,9 & 4,2 \\
\hline Bau pellet & Hari ke 0 & 3,5 & 3,2 & 3,0 & 3,0 \\
& Hari ke 7 & 3,3 & 3,1 & 2,8 & 2,7 \\
& Hari ke 14 & 3,4 & 3,3 & 3,0 & 2,6 \\
& Hari ke 21 & 3,3 & 3,0 & 2,9 & 2,8 \\
\hline Bau solid & Hari ke 0 & 3,8 & 3,6 & 3,4 & 3,0 \\
& Hari ke 7 & 4,0 & 3,6 & 3,0 & 2,7 \\
& Hari ke 14 & 3,6 & 3,0 & 2,7 & 2,3 \\
& Hari ke 21 & 4,0 & 2,8 & 2,7 & 2,1 \\
\hline
\end{tabular}

Keterangan : P0 : Tanpa mengandung lumpur sawit. P1 : 5\% Penggunaan lumpur sawit. P2 : 10\% Penggunaan lumpur sawit. P3 : 15\% Penggunaan lumpur sawit.

Pada uji warna semakin tinggi skor maka warna semakin hitam. Pada setiap perlakuan hari ke 0 sampai dengan hari ke 21 mengalami peningkatan nilai mulai P0 sampai P3. Pada penyimpanan pellet hari ke 0 memiliki kisaran skor 2,6-4,3, kisaran skor ini masuk dalam interval warna agak coklat sampai hitam. Rataan skor pada penyimpanan hari ke 7 memiliki kisaran skor 2,5-3,8, kisaran skor ini masuk dalam interval warna coklat sampai coklat kehitaman. Pada penyimpanan hari ke 14 memiliki kisaran skor 2,6-3,2, kisaran skor ini masuk dalam interval warna agak coklat. Pada penyimpanan hari ke 21 memiliki kisaran skor 2,1-4,2, kisaran ini masuk 
dalam interval coklat-hitam. menunjukan bahwa semakin banyak kandungan lumpur sawit pada pellet maka warna akan semakin hitam.

Berdasarkan hasil penelitian dapat disimpulkan bahwa semakin tinggi kandungan lumpur sawit pada pakan maka warnanya semakin gelap. Bahan pakan yang digunakan salah satunya solid berwarna hitam. Menurut Retnani et al., (2009), warna pellet ditentukan dari bahan penyusun pellet. Warna pakan pellet dari berbagai macam ternak cenderung berwarna coklat terang.Pada penelitian ini P1 lebih cenderung bagus karena warnanya tidak jauh berbeda dengan P0 (kontrol) Hal ini menunjukkan bahwa warna yang baik dalam pakan ternak bentuk pellet berwarna coklat terang Rakhmawati et al. (2017).

Pada uji bau pellet terdapat perbedaan antar perlakuan, semakin tinggi kandungan lumpur sawit pada pellet maka bau pellet semakin tengik. Pada perlakuan P0 sampai P3 mengalami penurunan dari penyimpanan hari ke 0 sampai hari ke 21 . Pada hari ke 0 terdapat perbedaan antar perlakuan yaitu pada P1, P2 dan P3 berbau agak tengik sementara P0 berbau tidak tengik. Rataan skor setelah penyimpanan hari ke 7 memiliki kisaran skor 3,3-2,7, kisaran ini masuk dalam interval agak tengik. Rataan skor setelah penyimpanan pada hari ke 14 terdapat perbedaan antar perlakuan yaitu pada P1, P2 dan P3 berbau agak tengik sementara P0 berbau tidak tengik dan rataan skor pada penyimpanan hari ke 21 memiliki rataan skor 3,3-2,8 masuk dalam skala interval agak tengik.

Berdasarkan hasil penelitian dapat ditarik kesimpulan bahwa pellet yang banyak mengandung lumpur sawit maka memiliki aroma yang tengik. Alviato et al. (2015) dan Kurniawan et al. (2016) menyatakan bahwa perubahan aroma juga disebabkan oleh bakteri yang merubah senyawa kompleks menjadi lebih sederhana. Bau pellet yang baik adalah bau yang menyerupai bahan baku pembuatan pellet, berbau segar dan tidak tengik. Hal tersebut sesuai dengan pendapat Rakhmawati et al. (2017) yang menyatakan bahwa bau yang dihasilkan pada pellet merupakan bau dari bahan baku pellet.

Hasil analisis bau solid menunjukkan terdapat perbedaan untuk setiap perlakuan dari P0, P1, P2 dan P3 yang menunjukkan penurunan skor yang berbeda beda. Pada hari ke 0 terdapat perbedaan antar perlakuan yaitu pada P0, P1 dan P2 tidak berbau solid sementara P3 agak berbau solid. Kemudian setelah penyimpanan hari ke 7 terdapat perbedaan antar perlakuan yaitu pada P0 dan P1 tidak berbau solid serta P2 dan P2 agak berbau solid. Selanjutnya setelah penyimpanan hari ke 14 terdapat perbedaan antar perlakuan dimana P0 tidak berbau solid sementara P1 dan P2 agak berbau solid dan P3 berbau solid. Selanjutnya setelah penyimpanan hari ke 21 terdapat perbedaan antar perlakuan dimana P0 tidak berbau solid sementara P1 dan P2 agak berbau solid dan P3 berbau solid. Dapat disimpulkan bahwa semakin lama penyimpanan maka skor bau solid semakin 
menurun. Dilihat dari skala interval bahwa skor bau semakin kecil akan semakin tercium aroma solid.

Aroma yang dihasilkan oleh pellet dari masing-masing perlakuan diduga dikarenakan adanya kombinasi bahan pakan yang berupa lumpur sawit, dimana lumpur sawit memiliki kandungan lemak yang tinggi. Lumpur sawit yang terpapar udara akan mengalami oksidasi yang mengakibatkan aroma menjadi tengik dan kandungan air yang tinggi. Utomo dan widjaja (2004) menyatakan, lumpur sawit mengandung 1,50\% CPO yang mengakibatkan lumpur sawit akan mudah menjadi tengik bila diletakkan ditempat terbuka. Aroma yang dihasilkan dari pellet pada hampir semua perlakuan memiliki aroma agak tengik yang dapat berpengaruh pada palatabilitas pakan jika diberikan pada ternak. Pendapat ini didukung oleh Durand (1989) dan Yusmadi et al (2008), yang menyampaikan bahwa faktor aroma pakan dapat menentukan tingkat konsumsi pakan jika diberikan pada ternak. Selain aroma dalam ransum yang mempengaruhi tingkat konsumsi, tekstur dan rasa juga dapat mempengaruhi palatabilitas pada pakan.

\section{Palatabilitas}

Kualitas pakan yang dibuat tidak hanya dilihat dari kandungan nutrisi dan tingkat kecernaan bahan pakan, tetapi juga dapat ditentukan oleh tingkat palatabilitas pakan yang diberikan. Palatabilitas merupakan tingkat kesukaan yang ditunjukan oleh ternak untuk mengkonsumsi suatu bahan pakan yang diberikan. Konsumsi pellet yang mengandung lumpur sawit disajikan pada Tabel 5.

Tabel 5. Rataan konsumsi pellet yang mengandung lumpur sawit

\begin{tabular}{ccccccc}
\hline \multirow{2}{*}{ Perlakuan } & \multicolumn{5}{c}{ Ulangan } & $\begin{array}{c}\text { Rata-rata } \pm \text { Standar } \\
\text { Deviasi }\end{array}$ \\
\cline { 2 - 5 } & $\mathrm{U} 1$ & $\mathrm{U} 2$ & $\mathrm{U} 3$ & $\mathrm{U} 4$ & $\mathrm{U} 5$ & \\
\hline & & \multicolumn{5}{c}{$\ldots . \mathrm{g} \ldots \ldots$} \\
P0 & 130,07 & 99,73 & 134,27 & 133,87 & 80,20 & $115,63 \pm 24,478$ \\
P1 & 92,73 & 106,07 & 89,87 & 145,73 & 74,93 & $101,87 \pm 26,901$ \\
P2 & 74,93 & 76,93 & 106,73 & 113,87 & 103,33 & $95,16 \pm 17,974$ \\
P3 & 122,20 & 113,00 & 125,27 & 134,53 & 69,60 & $112,92 \pm 25,408$ \\
\hline P & & \multicolumn{5}{c}{}
\end{tabular}

Keterangan : P0 : Tanpa mengandung lumpur sawit. P1 : 5\% Penggunaan lumpur sawit. P2 : 10\% Penggunaan lumpur sawit. P3 : 15\% Penggunaan lumpur sawit.

Hasil analisis menunjukkan bahwa perlakuan berpengaruh tidak nyata $(\mathrm{P}>0.05)$ terhadap tingkat konsumsi pada kelinci. Pada hasil penelitian konsumsi pakan pellet masing-masing perlakuan pada kelinci selama tiga hari (Tabel 5) berada pada kisaran 95,16 $\pm 17,974$ $115,63 \pm 24,478$ g. Tinggi rendahnya konsumsi pakan pada kelinci disebabkan dari faktor makanan yang kurang disukai oleh kelinci. Parakkasi (1999) menyatakan bahwa tingkat konsumsi juga dipengaruhi oleh berbagai faktor, diantaranya yaitu faktor ternak itu sendiri, pakan yang diberikan 
dan lingkungan ternak dipelihara. Lebih lanjut ditambahkan oleh (Church dan Pond, 1988), bahwa faktor yang mempengaruhi tingkat konsumsi pakan diantaranya adalah penampilan dan bentuk pakan, rasa, tekstur dan temperatur lingkungan.

\section{KESIMPULAN}

Pellet kelinci yang mengandung lumpur sawit sampai 15\% dengan lama simpan 21 hari tidak menurunkan daya simpan. Pellet yang mengandung lumpur sawit sampai dengan 15\% dengan lama simpan 7 hari tidak menurunkan palatabilitas pada kelinci.

\section{DAFTAR PUSTAKA}

Alviato, A., Muhtarudin dan Erwanto. 2015. Pengaruh penambahan berbagai jenis sumber karbohidrat pada silase limbah sayuran terhadap kualitas fisik dan tingkat palatabilitas silase. J. Ilmiah Peternakan Terpadu. 3(4) : 196 - 200.

Amiroh, I. 2008. Pengaruh Wafer Ransum Komplit Limbah Tebu Dan Penyimpanan Kualitas Sifat Fisik. Skripsi. Fakultas Peternakan. Institut Pertanian Bogor, Bogor.

Blas, C.D and J. Wiseman. 2010. Nutrition of The Rabbit. $2^{\text {nd }}$ Edition. CABI. Amerika.

Church, D.C. \& W.G. Pond. 1988. Basic Animal Nutrition and Feeding. 3nd Ed. John Wiley and Son, New York.

Direktorat Jenderal Perkebunan. 2012. Statistik Perkebunan Indonesia, Departemen Pertanian Jakarta.

Durand M. 1989. Conditions for optimizing cellulolytic activity in the rumen in evaluation of straw in ruminant feeding. Elsevier Applied Science, London and New York.

Haryanto, B. 2012. Perkembangan Penelitian Nutrisi Ruminansia. Balai penelitian Ternak, Bogor.

Ismi, R.S., R.I. Pujaningsih dan S. Sumarsih. 2017. Pengaruh penambahan level molases terhadap kualitas fisik dan organoleptik pellet pakan kambing periode penggemukan. JIPT. 5 (3) : $58-63$.

Junaida. 2013. Buku Petunjuk Teknis Metode Pengujian Pakan. Bekasi: Balai Pengujian Mutu dan Sertifikasi Pakan.

Kompiang, I.P., T. Purwadaria., T. Hartati dan Supriyati. 1997. Bioconversion of sago (Metroxylon sp.) waste. Current status of Agricultural Biotechnology in Indonesia.

Kurniawan, H., R. Utomo dan L. M. Yusiwati. 2016. Kualitas nutrisi kepala (Cocos nucifera L.) fermentasi menggunakan Aspergillus niger. Buletin Peternakan. 40 (1) : 26 - 33.

Lekito, M.N. 2002. Analisis kandungan nutrisi lumpur sawit asal pabrik pengolahan di Kec. Prafi, KAb. Manokwari, Papua. J. Peternakan dan Lingkungan, Vol. 08, No. 1, Februari 2001, Hal. 59-62.

McDonald, P., R. Edwards danJ. Greenhalgh. 2010. Animal Nutrition. 7th Ed. New York.

Nilasari. 2012. Pengaruh Penggunaan Ubi Jalar, Garuk dan Onggok Terhadap Sifat Fisik dan Lama Penyimpanan Ayam Broiler Bentuk Pellet. Skripsi. Fakultas Peternakan.Institut Pertanian Bogor, Bogor. 
Parakkasi A. 1990. Ilmu Nutrisi dan Makanan Ternak Monogastrik, 230. UI-Press, Jakarta.

Petterson, D.S., D.J. Harris., C.J. Rayner., A.B. Blakeney and M. Choct. 1989. Methods for the analysis of premium livestock grains. Australian Journal of Agricultural Research 50, 775-787.

Rakhmawati, Y.E., B. Sulistiyanto dan S. Sumarsih. 2017. Mutu fisik organoleptik pellet limbah penetasan dengan penambahan bentonit dan lama penyimpanan yang berbeda. Prosiding Seminar Nasional Teknologi Peternakan dan Veteriner, Bogor 8 - 9 Agustus 2017. p. 656 $-663$.

Retnani, Y., W. Widiarti, I. Amiroh, L. Herawati dan K. B. Satoto. 2009. Daya simpan dan palatabilitas wafer ransum komplit pucuk dan ampas tebu untuk sapi pedet. Media Peternakan. $32: 130-136$.

Said. 1996. Penanganan dan Pemanfaatan Limbah Kelapa Sawit. Trubus Agriwiya. Bogor. Sarwono, B. 2005. Kelinci Potong dan Hias. Agro Media Pustaka, Jakarta.

Trisyulianti, E., Suryahadi \& V.N. Rakhma. 2003. Pengaruh penggunaan molases dan tepung gaplek sebagai bahan perekat terhadap sifat fisik wafer ransum komplit. Med.Pet. 26: 3540 .

Utomo dan Widjaja. 2004. Limbah padat pengolahan minyak sawit sebagai sumber nutrisi ternak ruminansia. Jurnal Litbang Pertanian. 23(1): 22-28.

Yusmadi, Nahrowi, M. Ridla. 2008. Kajian mutu dan palatabilitas silase dan hay ransum komplit berbasis sampah organik primer pada kambing peranakan etawah. Jurnal Agripet, 8(1): 31-38.

Zang JJ, X Piao, DS Huang, J Wang, X Ma dan YX Ma. 2009. Effect of feed particle size and feed form on growth performance, nutrient metabolizability and intestinal morphology in Broiler chickens. Asian Australian J. Anim Sci. 22(1): 